\title{
Synaptic Wiring of Corticostriatal Circuits in Basal Ganglia: Insights into the Pathogenesis of Neuropsychiatric Disorders
}

\author{
Hsiao-Ying Kuo ${ }^{1}$ and Fu-Chin Liu ${ }^{1,2}$ \\ https://doi.org/10.1523/ENEURO.0076-19.2019 \\ ${ }^{1}$ Institute of Neuroscience, National Yang-Ming University, Taipei 11221, Taiwan, ${ }^{2}$ Brain Research Center, National \\ Yang-Ming University, Taipei 11221, Taiwan
}

\begin{abstract}
The striatum is a key hub in the basal ganglia for processing neural information from the sensory, motor, and limbic cortices. The massive and diverse cortical inputs entering the striatum allow the basal ganglia to perform a repertoire of neurological functions ranging from basic level of motor control to high level of cognition. The heterogeneity of the corticostriatal circuits, however, also renders the system susceptible to a repertoire of neurological diseases. Clinical and animal model studies have indicated that defective development of the corticostriatal circuits is linked to various neuropsychiatric disorders, including attention-deficit hyperactivity disorder (ADHD), Tourette syndrome, obsessive-compulsive disorder (OCD), autism spectrum disorder (ASD), and schizophrenia. Importantly, many neuropsychiatric disease-risk genes have been found to form the molecular building blocks of the circuit wiring at the synaptic level. It is therefore imperative to understand how corticostriatal connectivity is established during development. Here, we review the construction during development of these corticostriatal circuits at the synaptic level, which should provide important insights into the pathogenesis of neuropsychiatric disorders related to the basal ganglia and help the development of appropriate therapies for these diseases.
\end{abstract}

Key words: basal ganglia; corticostriatal circuits; neurodevelopmental diseases; striatum; synapse

\section{Significance Statement}

Cortico-basal ganglia circuits control a range of neurobiological functions, ranging from motor control and reward to cognition. The functional diversity of cortico-basal ganglia circuits rests on their diverse inputs from the cerebral cortex. It is likely that the highly heterogeneous nature of corticostriatal inputs makes the corticostriatal circuits vulnerable to a broad range of neurologic and psychiatric disorders. Here, we highlight the developmental progression and maturation of the morphology and physiology of corticostriatal pathways using neonatal and postnatal rodent brains. We also review the pathogenesis of various neurodevelopmental disorders that are related to dysfunctions of corticostriatal circuits. Exploring synaptic wiring of corticostriatal circuits should create a research window for the development of therapeutic approaches for treating basal ganglia-related neurologic disorders.

\section{Introduction}

An essential function of neural networks is the processing of sensory inputs and the generation of motor outputs.

Received February 28, 2019; accepted May 7, 2019; First published May 16, 2019.

The authors declare no competing financial interests.
The cortico-basal ganglia circuitry is in a key hub that is involved in the integration of sensory and motor information by the brain. The striatum of the basal ganglia re- 


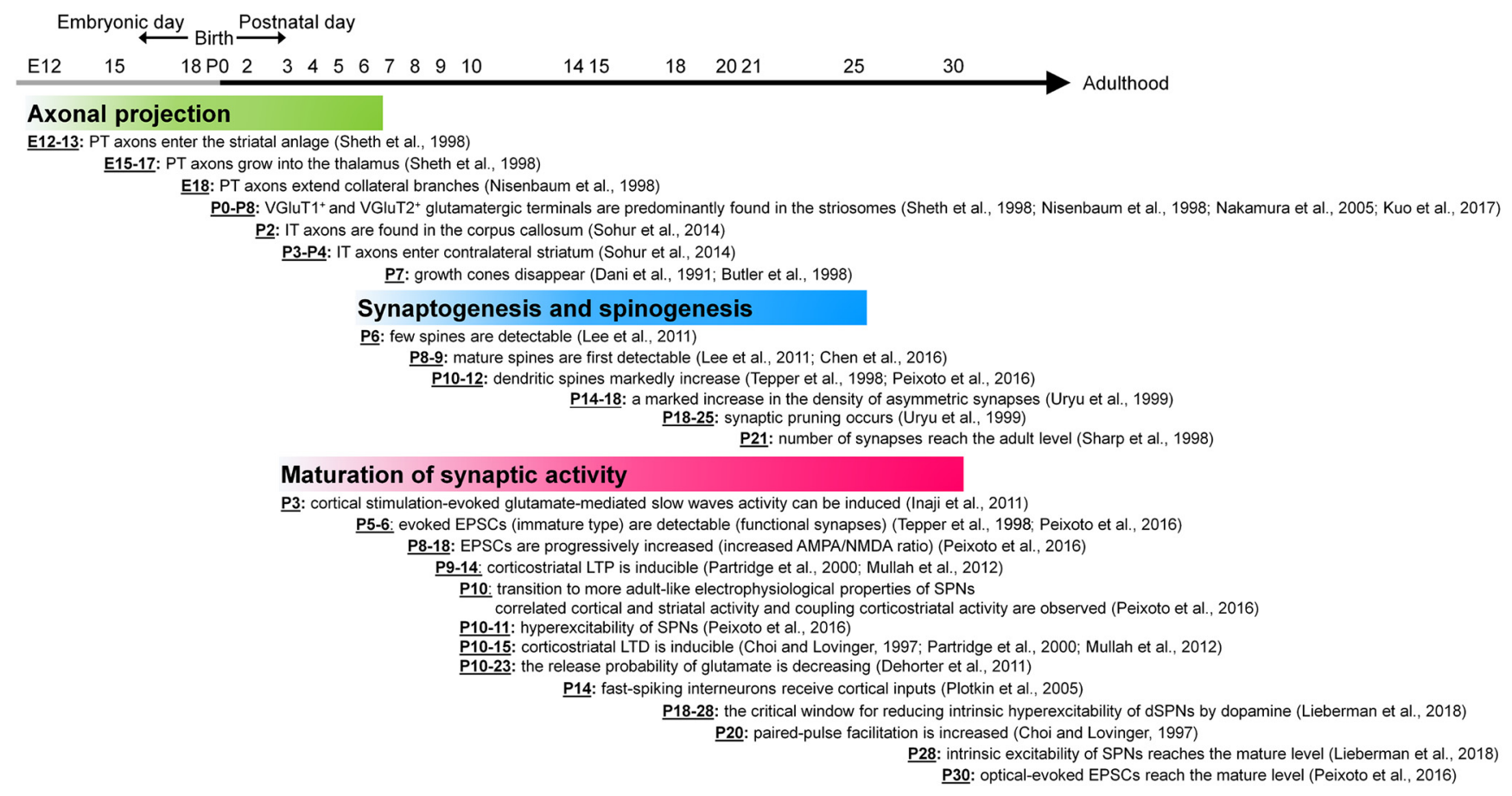

Figure 1. Developmental progression during the morphologic and physiologic maturation of corticostriatal innervations. AMPA: $\alpha$-amino-3-hydroxy-5-methyl-4-isoxazolepropionic acid; dSPN; direct striatonigral pathway neuron; EPSC: excitatory postsynaptic current; iSPN: indirect striatopallidal pathway neuron; IT: intratelencephalic; LTD: long-term depression; LTP: long-term potentiation; NMDA: N-methyl-D-aspartate; PT: pyramidal tract; SPN: striatal projection neuron; VGluT1: vesicular glutamate transporter 1; VGluT2: vesicular glutamate transporter 2 .

ceives a large number of cortical inputs from the motor, sensory, association and limbic cortices (Hintiryan et al., 2016; Hunnicutt et al., 2016). The corticostriatal afferents thus make up a wide range input of different nature into the basal ganglia. The corticostriatal inputs are highly heterogeneous and therefore the cortico-basal ganglia circuits are involved in processing a broad spectrum of neurobiological functions. These range from motor control at a basic level to high level adaptive learning and cognition (Alexander et al., 1986; Graybiel, 2008; Pennartz et al., 2009; Haber, 2016). The integration of sensory and motor information is essential for behavioral performance and thus it is not surprising that dysfunction of corticobasal ganglia circuits is well documented in a broad range of neurologic and mental disorders, including Parkinson's disease, Huntington's disease, attention-deficit hyperactivity disorder (ADHD), Tourette syndrome, obsessivecompulsive disorder (OCD), autism spectrum disorder (ASD), schizophrenia, and speech and language disorders (Crittenden and Graybiel, 2011; Shepherd, 2013; Gunaydin and Kreitzer, 2016).

Featured Areas Research Center Program within the framework of the Higher Education Sprout Project by the Ministry of Education in Taiwan (F.-C.L.), and Postdoctoral Fellowship Grants MOST107-2811-B-010-011 and MOST1072321-B-010-010-MY3 (to H.-Y.K.).

Correspondence should be addressed to Fu-Chin Liu at fuchin@ym.edu.tw https://doi.org/10.1523/ENEURO.0076-19.2019

Copyright $\odot 2019$ Kuo and Liu

This is an open-access article distributed under the terms of the Creative Commons Attribution 4.0 International license, which permits unrestricted use, distribution and reproduction in any medium provided that the original work is properly attributed.
Many psychiatric disorders are rooted in developmental dysfunctions that affect neural circuits within the brain. Thus, it is imperative to understand how neural circuits are formed during development. In this review, we have focused on the construction at the cellular and molecular level during development of the corticostriatal circuits. We have summarized the developmental maturation timeline of corticostriatal innervations in Figure 1.

Genetic studies using mouse models have shown that many genes important to the development of neural circuits are involved in the pathogenesis of neurologic and psychiatric disorders. The significance and biological functions of these building blocks of neural circuits are, in fact, best illustrated by pathologic studies of neuropsychiatric diseases. We have therefore also reviewed the pathophysiology of neuropsychiatric disorders where it is known that dysfunction of corticostriatal circuits is involved. A summary of the various animal model studies that have shown links to corticostriatal abnormalities and neuropsychiatric diseases is presented in Table 1.

\section{Establishment over Time of Corticostriatal Projections}

Corticofugal pathways form the major afferent inputs to the basal ganglia. In the developing mouse brain, corticofugal projection neurons are classified into two cell types: pyramidal tract (PT)-type cortical projection neurons and intratelencephalic (IT) projection neurons (Reiner et al., 2003, 2010). Previous studies have revealed the developmental projections of the PT-type corticostriatal pathway. 
Table 1. Susceptible genes in neurodevelopmental diseases that are modeled in transgenic mice

\begin{tabular}{|c|c|c|c|}
\hline Gene & $\begin{array}{l}\text { Associated } \\
\text { diseases }\end{array}$ & $\begin{array}{l}\text { Morphological and functional phenotypes in corticostriatal } \\
\text { circuits of transgenic mice carrying defective or } \\
\text { variant alleles of neurodevelopmental disorder-risk genes }\end{array}$ & References \\
\hline Drd4 & ADHD & $\downarrow$ corticostriatal glutamate release & Bonaventura et al. (2017) \\
\hline Shank3b & $\begin{array}{l}\text { ASD } \\
\text { OCD }\end{array}$ & $\begin{array}{ll}\uparrow & \text { dendritic arborizations } \\
\downarrow \text { synaptogenesis/spinogenesis } \\
\uparrow \text { precocious hyperactivity of corticostriatal inputs during development } \\
\downarrow \text { corticostriatal synaptic transmission in adulthood }\end{array}$ & $\begin{array}{l}\text { Peça et al. (2011) } \\
\text { Peixoto et al. (2016) }\end{array}$ \\
\hline Fmr1 & ASD & $\begin{array}{l}\uparrow \text { inhibitory neurotransmission in the striatum } \\
\downarrow \text { corticostriatal plasticity (LTD) } \\
\downarrow \text { corticostriatal connectivity }\end{array}$ & $\begin{array}{l}\text { Centonze et al. (2008) } \\
\text { Jung et al. (2012) } \\
\text { Zerbi et al. (2018) }\end{array}$ \\
\hline Foxp1 & ASD & $\uparrow$ excitability of iSPNs & Araujo et al. (2015) \\
\hline elf4e & ASD & $\begin{array}{l}\uparrow \text { spinogenesis in Layer II/III of medial prefrontal cortex } \\
\uparrow \text { corticostriatal plasticity (LTD) }\end{array}$ & Santini et al. (2013) \\
\hline Nlgn1 & ASD & $\begin{array}{l}\downarrow \text { NMDA-mediated synaptic transmission of dSPNs } \\
\downarrow \text { mEPSCs in iSPNs }\end{array}$ & $\begin{array}{l}\text { Blundell et al. (2010) } \\
\text { Espinosa et al. (2015) }\end{array}$ \\
\hline Nlgn3 & ASD & $\begin{array}{l}\downarrow \text { inhibitory synaptic transmission in dSPNs of the ventral striatum } \\
\downarrow \text { corticostriatal plasticity (LTD) }\end{array}$ & $\begin{array}{l}\text { Rothwell et al. (2014) } \\
\text { Martella et al. (2018) }\end{array}$ \\
\hline Tshz3 & ASD & $\uparrow$ corticostriatal LTP & Caubit et al. (2016) \\
\hline Met & $\begin{array}{l}\text { ASD } \\
\text { SLD }\end{array}$ & $\uparrow$ neuronal activity of corticostriatal pyramidal neurons in Layer Vb & Qiu et al. (2011) \\
\hline Mef2c & $\begin{array}{l}\text { ASD } \\
\text { SLD }\end{array}$ & $\begin{array}{l}\uparrow \text { synaptogenesis/spinogenesis in the striatum } \\
\uparrow \text { mEPSCs in SPNs }\end{array}$ & Chen et al. (2016) \\
\hline Cntnap2 & $\begin{array}{l}\text { ASD } \\
\text { SLD }\end{array}$ & $\downarrow$ number of striatal GABAergic interneurons & Peñagarikano et al. (2011) \\
\hline Slitrk5 & OCD & $\begin{array}{l}\downarrow \text { BDNF-mediated neurite outgrowth of striatal neurons } \\
\uparrow \text { neuronal activity of the orbitofrontal cortex } \\
\downarrow \text { corticostriatal transmission } \\
\downarrow \text { dendritic complexity of SPNs } \\
\downarrow \text { GluR2, NR2B in the striatum }\end{array}$ & $\begin{array}{l}\text { Song et al. (2015) } \\
\text { Shmelkov et al. (2010) }\end{array}$ \\
\hline Sapap3 & OCD & $\begin{array}{l}\downarrow \text { postsynaptic density thickness } \\
\uparrow \text { NR1, NR2B and } \uparrow \text { NR2A in the striatal PSD fraction } \\
\downarrow \text { corticostriatal field EPSP } \\
\downarrow \text { corticostriatal quantal EPSP in the iSPNs } \\
\downarrow \text { corticostriatal feedforward inhibition of fast-spiking interneurons }\end{array}$ & $\begin{array}{l}\text { Welch et al. (2007) } \\
\text { Wan et al. (2014) } \\
\text { Burguière et al. (2013) }\end{array}$ \\
\hline Slc1a1 & OCD & $\begin{array}{l}\downarrow \text { neuronal activity in response to amphetamine in the dorsal striatum } \\
\downarrow \text { NR2A and corticostriatal LTD in the dorsal striatum }\end{array}$ & $\begin{array}{l}\text { Zike et al. (2017) } \\
\text { Delgado-Acevedo et al. (2019) }\end{array}$ \\
\hline ErbB4 & Schizophrenia & $\begin{array}{l}\uparrow \text { inhibitory synaptic transmission in the striatum } \\
\uparrow \mathrm{GABA}_{\mathrm{A}} \alpha 1 \text { in the striatum }\end{array}$ & Geng et al. (2017) \\
\hline Zswim6 & Schizophrenia & $\begin{array}{l}\downarrow \text { neurite arborizations in the striatum } \\
\downarrow \text { spinogenesis in the striatum }\end{array}$ & Tischfield et al. (2017) \\
\hline Foxp2 & SLD & $\begin{array}{l}\downarrow \text { corticostriatal synaptic transmission } \\
\downarrow \text { corticostriatal plasticity (LTD) } \\
\downarrow \text { synaptogenesis/spinogenesis in the striatum } \\
\downarrow \text { mEPSCs in SPNs }\end{array}$ & $\begin{array}{l}\text { Groszer et al. (2008) } \\
\text { Enard et al. (2009) } \\
\text { Reimers-Kipping et al. (2011) } \\
\text { Chen et al. (2016) }\end{array}$ \\
\hline
\end{tabular}

ADHD: attention-deficit hyperactivity disorder; ASD: autism spectrum disorder; BDNF: Brain-derived neurotrophic factor; dSPN: direct striatonigral pathway

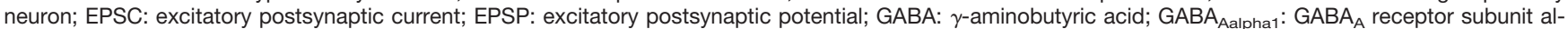
pha 1; GluR2: glutamate ionotropic receptor AMPA type subunit 2; iSPN: indirect striatopallidal pathway neuron; LTD: Iong-term depression; LTP: Iong-term potentiation; NR1: glutamate ionotropic receptor NMDA type subunit 1; NR2A: glutamate ionotropic receptor NMDA type subunit 2A; NR2B: glutamate ionotropic receptor NMDA type subunit 2B; mEPSC: miniature excitatory postsynaptic currents; OCD: obsessive-compulsive disorder; PSD: postsynaptic density; SLD: speech and language disorders; SPN: striatal projection neurons.

Nisenbaum et al. (1998) and Sheth et al. (1998) traced the developing corticofugal axons by placing Dil in fixed brain slices from a single hemisphere. The majority of the ipsilaterally Dil-labeled corticofugal axons are presumably derived from PT-type corticostriatal neurons, this is because the Dil-labeled axons can be traced and shown to exit the telencephalon to form part of the PT. However, because IT-type neurons project into both the ipsilateral and contralateral striatum, the possibility that some of the ipsilaterally Dil-labeled axons are derived from IT-type neurons cannot be excluded. Corticofugal axons have been found to enter the ipsilateral striatal anlage as early as embryonic day (E)12-E13. Corticofugal axons, presumably en route through the striatal analge during E12$\mathrm{E} 13$, continue growing into the thalamus during E15-E17. By E18, clusters of collateral branches of corticofugal axons can be found in the ipsilateral striatum. Notably, these corticostriatal fibers are predominately co-localized with the tyrosine hydroxylase-positive nigrostriatal dopamine islands that are known to mark the loci of developing striosomes before the postnatal day (P)8 (Nisenbaum et al., 1998; Sheth et al., 1998). To explore the developmental projections of IT-type cortical neurons, Sohur et al. (2014) performed retrograde and anterograde labeling of 
corticostriatal axons during the first two postnatal weeks, and found that IT-type corticostriatal axons enter the contralateral striatum during P3-P4, and these corticostriatal axons progressively refined their innervation over the first two weeks after birth (Sohur et al., 2014). Immunostaining of growth-associated protein 43, a growth cone-specific protein, is markedly down-regulated in the dorsal striatum after P7, which suggests that there is a decrease in axonal growth in this region after P7 (Dani et al., 1991; Butler et al., 1998). Therefore, IT-type corticostriatal innervation of the mouse brain mainly starts during the early stage of the first postnatal week, and these innervations become mature by the second postnatal week.

\section{Topography of the Corticostriatal Pathways}

Corticostriatal projections are topographically organized in such a manner as to convey neural information from various different cortical regions into the striatum where this diverse information is integrated. The dorsolateral/sensorimotor striatum, which is known to be involved in motor sequencing and habit-related functions, mainly receives its cortical inputs from the motor and somatosensory cortex. The dorsomedial/associative and ventral/limbic striata, which are related to goal-directed motor learning and reward, respectively, receive cortical inputs from the frontal cortex, mesocortex and allocortex (Alexander et al., 1986; McGeorge and Faull, 1989; Berendse et al., 1992; Mailly et al., 2013; Hintiryan et al., 2016; Hunnicutt et al., 2016). The deciphering of the topographic corticostriatal projection map has laid the foundations for understanding the functional networks related to a range of physiologic and pathologic conditions.

\section{Corticostriatal projections into striatal compartments}

Considering the axonal terminal fields in the striatum, it has been shown that corticostriatal axons from different cortical regions innervate the striosomal and matrix compartments with different weights. The striosomal compartment receives substantial cortical inputs from evolutionarily conserved areas of the cortex, including the prelimbic, anterior cingulate, orbitofrontal, and insular cortices. The surrounding matrix compartment receives cortical inputs from the neocortex, including the motor, somatosensory and visual cortices (Gerfen, 1984; Donoghue and Herkenham, 1986; Ragsdale and Graybiel, 1990; Flaherty and Graybiel, 1993, 1994; Eblen and Graybiel, 1995; Kincaid and Wilson, 1996).

When the laminar distribution of the corticostriatal neurons is explored, the early-born PT-type corticostriatal projection neurons in the rat brain have been found to be primarily located in lower Layer V (Layer Vb), from where they project their axons into the striosomes. By way of contrast, the late-born IT-type corticostriatal neurons are located in Layer III and upper Layer V (Layer Va), from where they predominantly project their axons into the matrix compartment (Gerfen, 1989; McGeorge and Faull,
1989; Cowan and Wilson, 1994; Kincaid and Wilson, 1996; Lévesque and Parent, 1998). Interestingly, a recent genetic study using virus-based axonal tracing has revealed that there is no preference regarding corticostriatal afferents entering into the striatal compartments of the mouse brain (Smith et al., 2016). Cre-dependent monosynaptic tracing via genetically modified rabies virus using compartment-specific Cre driver mice by Smith et al. (2016) has found that both the patch/exo-patch (striosome) compartment and the matrix compartment receive cortical innervations from the limbic and sensorimotor cortices without any preference. Cortical neurons in the upper and deep layers were shown to project into both the patch/exo-patch (striosome) compartment and the matrix compartment (Smith et al., 2016). Nonetheless, single-cell RNA sequencing has identified genetically distinct cell populations in a single cortical area (Tasic et al., 2016). It is possible that different populations of cortical neurons within a single cortical region may project differentially into the striatal compartments. A combination of the single-cell RNA sequencing linked with axonal tracing and behavioral studies may help to clarify the above issue.

\section{Corticostriatal projections linking to distinct striatofugal pathways}

Evidence based on retrograde axonal tracing and electron microscopy have shown that more corticostriatal axons of the IT-type compared to the PT-type are linked to neurons of the direct striatonigral pathway (dSPNs). In contrast, more PT-type than IT-type corticostriatal axons are linked to neurons of the indirect striatopallidal pathway (iSPNs; Lei et al., 2004; Reiner et al., 2010; Deng et al., 2015). When the efferent regions of the cortex are explored, it remains unclear as to whether there is differential innervation of dSPNs and iSPNs from distinct cortical regions (Berretta et al., 1997; Wall et al., 2013; Guo et al., 2015). Wall et al. (2013) have reported that axons from the sensory and limbic cortices preferentially innervate dSPNs, whereas axons from the motor cortex preferentially project toward iSPNs (Wall et al., 2013). However, Guo et al. (2015) did not find that there was differential innervation of dSPNs and iSPNs by the various different cortical regions. This inconsistency may be the result of variation in the degree of virus infection present in a single cortical region across the two studies. Alternatively, it also may be due to differences in trans-synaptic retrograde efficiency across the various different types of corticostriatal synapses (Guo et al., 2015).

\section{Corticostriatal Axonal Outgrowth and Synaptogenesis}

A coculture study has demonstrated the specificity of corticostriatal innervation by prenatal and postnatal cortical afferents. During cortical and striatal coculture, neurites derived from the prenatal cortex homogeneously grow into co-cultured striatal tissue, while, on the other hand, neurites derived from perinatal stages specifically grow into the striosomal compartment of co-cultured striatum irrespective of the age of the striatal tissue. Only a small amount of neurite innervations can be found in 
striatal tissue when it is co-cultured with postnatal cortex (Snyder-Keller, 2004). These results suggest a timedependent interplay between the different cortical afferents and the striatum. Because corticostriatal axonal innervation occurs before synaptogenesis and functional connectivity is established during the postnatal period (see below), corticostriatal axonal innervation during the various embryonic stages may occur without much in the way of activity modulation from the cortex.

Corticostriatal synaptogenesis occurs postnatally after corticostriatal axonal innervation has been established. A cell culture study has shown that cortical synaptic inputs into the striatum are important for maturation of the dendritic arborization of the SPNs (Buren et al., 2016). SPNs receives glutamatergic excitatory inputs from VGluT1positive corticostriatal neurons and VGluT2-positive thalamostriatal neurons (Fremeau et al., 2001, 2004). Corticostriatal and thalamostriatal axonal terminals form axospinous and axodendritic synapses with the SPNs, respectively (Dubé et al., 1988). The synaptogenesis of the excitatory synapses occurs soon after axonal innervations during postnatal periods. Interestingly, VGluT1 and VGluT2 immunoreactivity are highly enriched in striosomal loci during the first postnatal week, suggesting that corticostriatal and thalamostriatal synapse formation start to occur in the neonatal striosomal compartment (Nakamura et al., 2005; Kuo and Liu, 2017). The dendritic spines of SPNs are found low in the P6 striatum, and mature types of dendritic spines are first able to be detected during the period P8-P9 (Lee and Sawatari, 2011). Dendritic spines markedly increase in number during the period P10-P12, at which time the SPNs are at their most excitable during the postnatal period. Dendritic spines continue to increase until the fourth postnatal week (Tepper et al., 1998; Chen et al., 2016; Peixoto et al., 2016). The numbers of asymmetric synapses found in the P21 striatum at this time are comparable to those found in the adult rat striatum (Sharpe and Tepper, 1998). Considering the synaptic pruning, there is a dramatic decrease in dendritic spines that occurs within the dorsolateral rat striatum, but not the dorsomedial rat striatum from P18 to P25 (Uryu et al., 1999). It should also be noted that synaptic pruning by microglia has also been documented in the postnatal brain (Paolicelli et al., 2011; Wu et al., 2015).

During the early postnatal stages, developmental maturation of the electrophysiological properties of the SPNs involves immature SPNs that are characterized by a depolarized resting membrane potential together with hyperexcitability and a lack of inward rectification (Tepper et al., 1998; Peixoto et al., 2016). When developmental maturation of corticostriatal innervations of SPNs occurs, this happens in parallel concomitant with developmental corticostriatal innervations and dendritic spinogenesis, while at the same time cortical stimulation-evoked glutamate-mediated slow wave activity is able to be induced in the SPNs of P3 brain slices as shown by a voltage-sensitive dye (Inaji et al., 2011). By P5-P6, electrical-evoked and optical-evoked EPSCs are able to be detected in SPNs, suggesting the presence of func- tional corticostriatal synapses at this stage (Tepper et al., 1998; Peixoto et al., 2016). Optical-evoked EPSCs progressively increase with the gradual recruitment and stabilization of AMPA receptors during the period P8-P18. Optical-evoked EPSCs reach a mature level by P30 (Peixoto et al., 2016). Interestingly, a decrease in the release probability of glutamate during the development of the corticostriatal synapses has been observed during striatal long-term depression (LTD) over the period P10-P23, which correlates with the motor function developmental maturation. Moreover, it has been reported that a loss of NMDA NR2C/D-mediated corticostriatal inputs occurs concurrently with a decrease in an immature pattern of striatal activity before P10 and that this is correlated with the onset of locomotion by the neonatal mouse pups (Dehorter et al., 2011).

Cortical synaptic inputs not only drive synaptic activity in SPNs, but are also able to indirectly inhibit SPN activity via fast-spiking interneuron-mediated feed-forward inhibition (Plotkin et al., 2005). Electrophysiological recordings of fast-spiking interneurons in the striatum of rat brain slices obtained during the periods P12-P14 and P19-P23 have shown that fast-spiking interneurons have received frequent cortical inputs by the end of the second week after birth, which is when corticostriatal synaptogenesis is ongoing. This suggests a potential role for fast-spiking interneuron-mediated cortical feed-forward inhibition during the development of corticostriatal circuits (Plotkin et al., 2005).

In the dorsolateral striatum, corticostriatal long-term potentiation (LTP) is inducible as early as P9-P10, whereas LTD cannot be induced until P15 (Choi and Lovinger, 1997; Partridge et al., 2000; Mullah et al., 2012). This developmental transition affecting the synaptic plasticity of LTD is controlled by upregulation of the endogenous cannabinoid ligand anandamide (Ade and Lovinger, 2007). The release probability of glutamate from cortical axonal terminals has been shown to decrease from P10 to P23, which may account for the induction of striatal LTD. LTD is known to be a physiologic mechanism that underlies motor performance, learning, and memory. Taken together, the above findings delineate the functional maturation process during postnatal development of corticostriatal synaptogenesis.

\section{Neuronal Activity-Dependent Regulation of Corticostriatal Synaptogenesis during Development}

\section{Glutamate inputs}

A previous study has suggested that recurrent activity in the closed loops of cortico-basal ganglia circuits is able to regulate the synaptogenesis of SPNs (Kozorovitskiy et al., 2012). Synaptic connectivity and the strength of corticostriatal pathways are subject to regulation by the outputs from basal ganglia circuits. Chronic inhibition of activity within dSPNs and iSPNs during the second postnatal week by chemogenetic manipulation has been shown to result in decreased and increased spinogenesis and miniature EPSCs (mEPSCs) in dSPNs and iSPNs, respectively (Kozorovitskiy et al., 2012). Acute and 
chronic elevation of cortical activity by the inactivation of cortical interneurons or the optogenetic activation of corticostriatal axonal terminals has been shown to increase the synaptic connectivity of the corticostriatal pathways during early development (Peixoto et al., 2016). Moreover, correlated increases in cortical and striatal activity has been observed during the period P10-P16 (Peixoto et al., 2016). These findings suggest that corticostriatal inputs are capable of modulating activity-dependent synaptogenesis in the SPNs.

\section{Dopamine inputs}

Dopaminergic inputs into basal ganglia circuits have been suggested to regulate corticostriatal maturation. Mesostriatal dopaminergic afferents start to innervate the striatum during early embryonic stages. At the perinatal stage, mesostriatal dopaminergic axonal terminals form "dopamine islands" that correspond to the developing striosomes (Olson et al., 1972; Graybiel, 1984; van der Kooy, 1984). During the period P8-P13, activation of $\mathrm{G} \alpha_{\mathrm{s}}$-coupled G-protein receptors in SPNs by a D1 agonist is able to increase corticostriatal activity and the number of dendritic spines (Kozorovitskiy et al., 2015). Furthermore, depletion of dopamine input into the P2 striatum weakens not only SPN activity in response to cortical stimulation, but also impairs the corticostriatal synchronization that accompanies locomotion induced hyperactivity during the period P21-P25 (Galiñanes et al., 2009).

Moreover, the imbalances in dopamine D1 and D2 signaling in SPNs that occur before the first two postnatal weeks has been shown to lead to significant alterations in corticostriatal innervation and spinogenesis (Kozorovitskiy et al., 2012). A recent study has further shown that nigrostriatal dopamine release during a critical period between P18 and P28 is required to reduce the intrinsic hyperexcitability of neonatal dSPNs to the level found in adults (Lieberman et al., 2018). Taken together, the above compelling evidence highlights the importance of dopamine transmission, not only in the regulation of the postnatal maturation of SPNs, but also it associated with the pathogenic mechanisms related to neurodevelopmental disorders.

\section{Brain-derived neurotrophic factor (BDNF)}

BDNF is one of the most studied neurotrophins and has been shown to be involved in the pathogenesis of various neurodevelopmental and neuropsychiatric disorders (Autry and Monteggia, 2012; Park and Poo, 2013). BDNF binds to tyrosine receptor kinase $B$ (TrkB) to transduce signals within developing neurons. Evidence from BDNF and TrkB conditional knock-out mice has indicated that BDNF-TrkB signaling regulates the neuronal survival, morphogenesis and synaptogenesis of striatal neurons (Baydyuk et al., 2011; Li et al., 2012); furthermore, presynaptic BDNF secretion is required for activitydependent corticostriatal LTP (Park et al., 2014). Notably, TrkB expression is enriched in the striosomal compartment during the first postnatal week when corticostriatal axons are selectively innervating striosomal cells (Costantini et al., 1999). These findings raise an intriguing possibility that BDNF-TrkB signaling may be involved in setting up within the striatal compartments the temporal order during activity-dependent corticostriatal synaptogenesis; this could involve initiating the initial steps of synapse formation within the striosomal compartment.

\section{Neuropsychiatric Diseases Related to Dysfunction of the Corticostriatal Circuits}

\section{Attention-deficit hyperactivity disorder (ADHD)}

ADHD is a neurodevelopmental disease that is characterized by symptoms including inattention and/or hyperactive/impulsive behaviors that persist for more than six months (American Psychiatric Association, 2013). Based on neuroimaging and genetic studies, abnormal neural connectivity and abnormal neurologic functioning are believed to underlie the pathology of ADHD brains (Mueller et al., 2017). Aberrant neural circuits, including dorsal frontostriatal, orbitofrontostriatal, prefrontostriatal, and frontoparietal circuits, have been identified as being associated with ADHD (Durston et al., 2011; Hong et al., 2015; Mueller et al., 2017).

Many ADHD studies have centred on dysfunction of the dopaminergic system (Levy, 1991). Dopamine neurotransmission is essential for motor control, reward learning, and motivation (Björklund and Dunnett, 2007; Gerfen and Surmeier, 2011). In addition to regulating neurotransmission within the adult brain, dopamine also plays an important role in neural development. Notably, depletion of dopamine by intraventricular injection of 6-hydroxydopamine (6-OHDA) into neonate rodent brains has been shown to induce an ADHD-like behavioral phenotype; furthermore, abnormal development of corticostriatal pathways and synaptogenesis has been found in 6-OHDA-treated brains (Galiñanes et al., 2009; Braz et al., 2015). Moreover, altered frontostriatal functional connectivity, which has linked to a reduction in the dendritic arborizations of SPNs, in particular iSPNs, has been also observed in juvenile 6-OHDA-treated mice. These neonatal 6-OHDAinduced pathologic changes become more severe in adult mice compared to juvenile mice (Braz et al., 2015). Transgenic knock-in mice expressing a human DRD4 polymorphic variant associated with ADHD have been shown to exhibit a decrease in corticostriatal glutamate release (Bonaventura et al., 2017). These different lines of evidence suggest that the corticostriatal development controlled by dopaminergic transmission may underlie ADHD pathophysiology.

\section{Autism spectrum disorder (ASD)}

ASD is a highly heterogeneous disease. The core symptoms of ASD include impaired social communication functioning and self-interest related repetitive behaviors (American Psychiatric Association, 2013; Wingate et al., 2014). Aberrant synaptogenesis, plasticity and excitatory/ inhibitory balance are believed to be involved in ASD pathophysiology (Toro et al., 2010; Bourgeron, 2015; Nelson and Valakh, 2015). The complex yet specific symptoms of ASD pathogenesis are presumably caused by aberrant wiring of specific neural circuits in the ASD brain. Evidence suggests that dysfunction of the basal ganglia circuits plays an important role in ASD pathogenesis and 
is related to repetitive behavior and defective social communication (Portmann et al., 2014; Ellegood et al., 2015; Fuccillo, 2016). Clinical studies have reported that there is an increase in the volume of the striatum that is positively correlated with the repetitive behaviors, the social deficits and the communicational deficits of the patients (Hollander et al., 2005; Rojas et al., 2006). Neuroimaging studies have shown a correlation between inward surface deformation affecting distinct striatal regions and impaired motor skills, praxis and poorer social communication (Qiu et al., 2010). Moreover, reduced long-range functional connectivity between the right inferior frontal cortex and the right caudate has been observed in brain of children suffering from ASD (Lee et al., 2009). These findings imply that there are dysfunctions that affect the corticostriatal and striatofugal circuits of ASD brains. Many genes that have been associated with ASD have been found to be related to corticostriatal development and synaptogenesis, including the Shank gene family and the Neuroligin (NLGN) gene family. Shank1, Shank2, and Shank3 are members of a postsynaptic scaffolding $\mathrm{SH} 3$ and multiple ankyrin repeat domains protein family. Mutations of the Shank family proteins are associated with autism and a number of other neuropsychiatric disorders (Phelan, 2008; Leblond et al., 2014; Monteiro and Feng, 2017). Mutation of the ASD-risk gene Shank3B, which is the most well-studied isoform, has been found to be enriched in corticostriatal regions, and to be associated with an increase in dendritic arborizations and a decrease in dendritic spinogenesis and synaptogenesis of SPNs (Peça et al., 2011). Mutation of Shank3B also leads to precocious hyperactivity of corticostriatal inputs due to the presence of cortical hyperactivity during P14; while, in contrast, lower levels of corticostriatal connectivity have been found in adult brains with this mutation (Peça et al., 2011; Peixoto et al., 2016).

Mutations affecting the NLGN gene family induce corticostriatal synaptopathy and this seems to be related to the ASD pathogenesis (Sudhof, 2008). For example, NLGN3 mutant mice exhibit increased inhibitory synaptic transmission in dSPNs of the ventral striatum and impaired corticostriatal LTD in the dorsal striatum (Rothwell et al., 2014; Martella et al., 2018). NLGN1, another NLGN member that has recently been identified as an ASD-risk gene (Nakanishi et al., 2017), has been shown to regulate NMDA-mediated synaptic transmission in dSPNs and mEPSC frequency in iSPNs (Blundell et al., 2010; Espinosa et al., 2015).

In addition to genes in the Shank and NLGN families, other ASD risk genes also seem to alter corticostriatal connectivity and activity. Human transcriptome analysis has identified Teashirt zinc-finger homeobox family member 3 (TSHZ3) as a hub gene that is involved in the development of cortical projection neurons. Patients with deletion mutation of the TSHZ3 gene exhibit ASD symptoms, and an animal model study has shown that there is an increase in corticostriatal LTP in Tshz3 heterozygous mice (Caubit et al., 2016). Furthermore, Fmr1 encodes the fragile $X$ mental retardation protein that is involved in autistic Fragile $X$ syndrome. In Fmr1 knock-out mice, an increase in inhibitory neurotransmission and defects in LTD have been found in the striatum and this has been linked with hypoconnectivity of the corticostriatal pathways (Centonze et al., 2008; Jung et al., 2012; Zerbi et al., 2018). Eukaryotic translation initiation factor $4 E$ (elF4E) is another gene associated with ASD susceptibility (NevesPereira et al., 2009). Overexpression of elF4E in transgenic mice results in increased dendritic spines in Layers II and III of the medial prefrontal cortex as well as enhanced striatal LTD (Santini et al., 2013). Mutation of transcription factor forkhead box p1 (Foxp1), an ASD-risk gene, is known to increase the neuronal excitability of iSPNs during P18 (Araujo et al., 2015). Finally, a reduction in putative cortico-striosomal synaptogenesis has been found in the P8 striatum of a ASD mouse model involving maternal treatment of mice with valproic acid (Kuo and Liu, 2017). Collectively, the above animal model studies suggest that dysfunction of corticostriatal synaptic homeostasis and disruption of synaptogenesis during development may contribute to the pathologic mechanisms of ASD.

\section{Obsessive-compulsive disorder (OCD)}

OCD is a neurodevelopmental disease wherein dysfunction of corticostriatal circuits at the neural circuit level is implicated in the pathology of the disease. Neuroimaging studies have found abnormalities of corticostriatal pathways, including the orbitofrontal cortex, prefrontal cortex, anterior cingulate cortex and striatum in the brains of patients with OCD (Harrison et al., 2009; Rotge et al., 2009; Anticevic et al., 2014; Hou et al., 2014; Jung et al., 2017). The pathologic alterations in these corticostriatal circuits have been correlated with the severity of the patient's OCD symptoms (Harrison et al., 2013). Moreover, repetitive transcranial magnetic stimulation and deep-brain stimulation-induced changes in corticostriatal activity seem to be able to cause alterations in the symptoms in OCD patients (Figee et al., 2013; Dunlop et al., 2016), which supports a causal relationship between dysfunction of corticostriatal circuits and OCD pathogenesis (Burguière et al., 2015; Fettes et al., 2017). Animal model studies have shown that chronically optogenetic activation of the orbitofronto-ventral striatum pathways is sufficient to bring about a progressive increase in the obsessive grooming behavior of mice, and that fluoxetine, a clinical drug used to treat $O C D$, is able to alleviate the optogenetic-induced obsessive grooming behaviors (Ahmari et al., 2013).

At the genetic level, mutations of several genes have been associated with OCD. It is notable that corticostriatal circuitry appears to be a convergent pathologic locus that is targeted by several OCD-risk genes, these include synapse-associated protein 90/postsynaptic density protein 95-associated protein 3 (SAPAP3) and members of the Slitrk gene family. SAPAP3 is an excitatory postsynaptic scaffold protein. Mutations of SAPAP3 have been found in patients with OCD (Züchner et al., 2009). Sapap3 knock-out mice exhibit defects affecting the structure of the postsynaptic complex and show a OCD-like behavioral phenotype. Moreover, the synaptic activity of the 
corticostriatal pathways, but not the thalamostriatal pathways, are altered, which indicates that the corticostriatal pathways seem to be specifically relevant to OCD pathophysiology (Welch et al., 2007; Wan et al., 2014). Compulsive grooming, an abnormality associated with Sapap3 knock-out mice, is able to be rescued by optogenetic activation of parvalbumin-positive fast-spiking interneuron-mediated feed-forward inhibition of the orbitofrontal-striatal circuits (Burguière et al., 2013). The Slitrk gene family is known to regulate synaptogenesis (Takahashi et al., 2012; Yim et al., 2013). Mutations of Slitrk gene family members are associated with various neuropsychiatric diseases, including Tourette syndrome and OCD (Abelson et al., 2005; Ozomaro et al., 2013). Slitrk5 is known to regulate the recruitment of TrkB into the postsynaptic regions to bring about BDNF-mediated neurite outgrowth of striatal neurons (Song et al., 2015). Genetic deletion of Slitrk5 not only results in neuronal hyperactivity in the orbitofrontal cortex, but also causes a reduction in corticostriatal transmission and dendritic complexity that is associated with OCD-like behaviors (Shmelkov et al., 2010).

In addition to mutation of the SAPA3 and Slitrk5 genes, mutations of the SLC1A1 and Hoxb8 genes have been shown to be related to abnormalities in corticostriatal activity and to changes in corticostriatal connectivity that have in turn been associated with OCD phenotypes. The SLC1A1 gene encodes neuronal glutamate/aspartate/ cysteine transporter excitatory amino acid transporter 3 (EAAT3). An abnormal increase in SLC1A1 expression with a parallel decrease in EAAT3 activity, have been found in the brains of patients with OCD (VeenstraVanderWeele et al., 2001; Dickel et al., 2006; Wendland et al., 2009). EAAT3-deficient mice exhibit diminished basal ganglia-dependent stereotypic behavior (Zike et al., 2017). A recent study has further reported that NMDA receptor subunit composition and NMDA-dependent synaptic plasticity are altered in mice overexpressing EAAT3 and this is linked to OCD-like behavioral deficits; these deficits can be rescued by antipsychotic treatment (Delgado-Acevedo et al., 2019). Interestingly, Hoxb8 function in microglia has been suggested to be involved in the pathogenesis of OCD via regulation of the corticostriatal circuits. Hoxb8 gene knock-out has been shown to induce an expansion in cortical synapses and contraction in striatal synapses. These changes then lead to an enhancement of corticostriatal activity in the Hoxb8 mutant mice, which can be seen to exhibit compulsive grooming behavior (Greer and Capecchi, 2002; Nagarajan et al., 2018).

\section{Schizophrenia}

Schizophrenia is a neurodevelopmental disease. Imbalanced excitatory/inhibitory transmission and abnormal synaptic function have been implicated in the pathophysiology of schizophrenia. Genetic linkage studies have indicated that the AKT1 and PRODH genes are associated with schizophrenia (Albert et al., 2002; Kempf et al., 2008; Thiselton et al., 2008). Elevated frontostriatal connectivity, particular in the dorsolateral prefrontal cortex, is present in subjects carrying AKT1 and PRODH variant alleles
(Meyer-Lindenberg et al., 2007; Kempf et al., 2008; Tan et al., 2008). Corticostriatal dysfunction affecting cognitive learning and reward processing have been identified among patients with schizophrenia (Wagshal et al., 2014; de Leeuw et al., 2015). In animal studies, NRG1-ErbB4 signaling (Jaaro-Peled et al., 2009) has been proposed to underlie the pathogenesis of schizophrenia. Conditional deletion of ErbB4 in Dlx5/6 cell lineage cells, including SPNs and cortical interneurons, results in enhanced inhibitory synaptic transmission in the striatum (Geng et al., 2017). Loss of zinc-finger SWIM domain-containing protein 6 (ZSWIM6), another schizophrenia-risk gene, has been shown to decrease neurite arborization and the number of dendritic spines in SPNs (Tischfield et al., 2017). Abnormal dopamine transmission has been a prevailing theory for the etiology of schizophrenia (Simpson et al., 2010). In this context, it is interesting to note that mesostriatal dopamine input during development is able to modulate corticostriatal innervations, spinogenesis and activity during development (Galiñanes et al., 2009; Kozorovitskiy et al., 2012; Lieberman et al., 2018). These findings suggest that abnormal synaptic wiring within the corticostriatal circuits may be a potential pathologic mechanism that underlies abnormal dopamine neurotransmission in schizophrenia brains.

\section{Speech and language disorders}

Speech and language are unique and fundamental to human beings and their social communication. The prevalence rate for language delay during the development of school children is high, which calls for a better understanding of the neurobiology of speech and language and the development of new therapeutic approaches to such problems. Cortico-basal ganglia circuits are important to speech and language (Watkins et al., 1999; Dick et al., 2014; Graham and Fisher, 2015; Konopka and Roberts, 2016). Several genes related to speech and language have been identified using genome-wide linkage/association sequencing studies (Newbury and Monaco, 2010; Kang and Drayna, 2011; Graham and Fisher, 2015; Konopka and Roberts, 2016). A well-studied speech and language-related gene is FOXP2. The FOXP2 R553H missense mutation caused severe level of speech and language disorder in the KE family (Lai et al., 2001). Neuroimaging studies have found structural abnormalities as well as functional abnormalities that affect the cerebral cortex and striatum of patients with a FOXP2 mutation. This suggests there is involvement of cortico-basal ganglia circuits in the pathology of this disorder (Watkins et al., 1999; Liégeois et al., 2003). Consistent with the above, animal studies have indicated that the corticobasal ganglia circuits are critical to vocal communication in songbirds and rodents (Enard et al., 2009; Fisher and Scharff, 2009; Arriaga et al., 2012; Condro and White, 2014; Konopka and Roberts, 2016). Increasing evidence indicates that Foxp2 plays a crucial role in the neural development and plasticity of corticostriatal circuits. Mutation of the Foxp2 gene decreases synaptic transmission and plasticity in corticostriatal synapses (Groszer et al., 2008; Enard et al., 2009; Reimers-Kipping et al., 2011). 
Humanized Foxp2 gene has been shown to increase synapse formation and synaptic functioning in the SPNs from mouse brains (Enard et al., 2009; Chen et al., 2016). It is important to note that developmental deficits in spoken language function are a comorbidity associated with various other psychiatric disorders, including ASD in which vocal communication can also be severely affected. Interestingly, Foxp2 has been shown to negatively regulate several ASD-risk genes, including Cntnap2, Met, and Mef2c (Vernes et al., 2008; Mukamel et al., 2011; Chen et al., 2016). Our recent study has uncovered a molecular mechanism by which Foxp2 promotes the synaptogenesis of corticostriatal circuits via suppression of Mef2c, a negative regulator of synapse formation. The Foxp2Mef2c signaling-mediated synaptic wiring of corticostriatal circuits has a causative role in vocal communication (Chen et al., 2016). Cntnap2 may modulate corticostriatal inputs via regulation of the development of striatal GABAergic interneurons (Peñagarikano et al., 2011). Finally, Met knock-out mice have been shown to exhibit hyperactivity of corticostriatal pyramidal neurons in cortical Layer Vb, which may affect the development of corticostriatal pathways (Qiu et al., 2011).

Cortico-basal ganglia circuits engage with other neural circuits to control complex neurobiological functions such as speech and language. The corticostriatal circuits may be a good entry point by which one may explore the developmental basis of vocal communication and this should be able to provide insights into the pathogenesis of various speech and language disorders.

\section{Tourette syndrome}

Tourette syndrome is a childhood-onset neurodevelopmental disease that is characterized by involuntary vocal and motor tics. Tourette syndrome is categorized as one of the three tic disorders in DSM-V (American Psychiatric Association, 2013). Tourette syndrome is a heterogeneous disorder that shows comorbidity with other neuropsychiatric diseases, including OCD and ADHD (Hirschtritt et al., 2015). The pathophysiology of Tourette syndrome is poorly understood. At the circuit level, increasing evidence had implicated pathologic changes in cortico-striato-pallido-thalamic circuits within the brains of patients with Tourette syndrome (McNaught and Mink, 2011). Neuroimaging studies have found abnormal increases in structures associated with corticostriatal connectivity, and these are further correlated with the severity of the tics (Govindan et al., 2010; Worbe et al., 2015), At the genetic level, twins siblings studies of individuals with Tourette syndrome have indicated that the concordance rate of monozygotic twins is higher than that of dizygotic twins (McNaught and Mink, 2011). Furthermore, genetic studies have identified a number of candidate genes that are associated with Tourette syndrome. One possible candidate gene is the Slit and Trk-like 1 (SLITRK1) gene. Patients carrying SLITRK1 variant alleles have known to exhibit Tourette syndrome (Abelson et al., 2005). Slitrk1 is expressed at high levels in cortical Layers III, V, and VI, which is where the corticostriatal and corticothalamic projection neurons are located in the mouse brain. Slitrk1 is also highly expressed in postnatal striosomes. Expression of slitrk1 has been shown to be significantly down-regulated after the second postnatal week, which is when corticostriatal innervation and synaptogenesis occur. The expression pattern of SLITRK1 in the cerebral cortex and striatum of the human brain is similar to that found in the monkey brain and the mouse brain (Stillman et al., 2009). Previous studies have shown that Slitrk1 positively regulates dendrites outgrowth and synaptogenesis in cortical pyramidal neurons and hippocampal neurons (Abelson et al., 2005; Yim et al., 2013; Beaubien et al., 2016). Given that Slitrk1 is expressed during the development of corticostriatal pathways, a potential role for Slitrk1 in the regulation of corticostriatal connectivity and its possible involvement in Tourette syndrome warrants further investigation.

\section{Conclusion}

A broad repertoire of genetic components participates in the synaptic wiring of the corticostriatal circuits during development. Activity-dependent machinery is also adopted to fine tune synaptogenesis to develop precise functionality within the cortico-basal ganglia network. Characterization of the development and functioning of corticostriatal circuits may not only help us to understand the developmental basis of motor control, skill development and habit learning as well as complex cognitive functions such as speech and language, but may also provide insights into the pathophysiology of corticostriatal circuits-related neurologic and psychiatric disorders. This, in turn, may lead to the identification of potential therapeutic approaches to the treatment of these important diseases.

\section{References}

Abelson JF, Kwan KY, O’Roak BJ, Baek DY, Stillman AA, Morgan TM, Mathews CA, Pauls DL, Rasin MR, Gunel M, Davis NR, Ercan-Sencicek AG, Guez DH, Spertus JA, Leckman JF, Dure LS 4th, Kurlan R, Singer HS, Gilbert DL, Farhi A, et al. (2005) Sequence variants in SLITRK1 are associated with Tourette's syndrome. Science 310:317-320.

Ade KK, Lovinger DM (2007) Anandamide regulates postnatal development of long-term synaptic plasticity in the rat dorsolateral striatum. J Neurosci 27:2403-2409.

Ahmari SE, Spellman T, Douglass NL, Kheirbek MA, Simpson HB, Deisseroth K, Gordon JA, Hen R (2013) Repeated cortico-striatal stimulation generates persistent OCD-like behavior. Science 340: 1234-1239.

Albert KA, Hemmings HC Jr, Adamo Al, Potkin SG, Akbarian S, Sandman CA, Cotman CW, Bunney WE Jr, Greengard P (2002) Evidence for decreased DARPP-32 in the prefrontal cortex of patients with schizophrenia. Arch Gen Psychiatry 59:705-712.

Alexander GE, DeLong MR, Strick PL (1986) Parallel organization of functionally segregated circuits linking basal ganglia and cortex. Annu Rev Neurosci 9:357-381.

Anticevic A, Hu S, Zhang S, Savic A, Billingslea E, Wasylink S, Repovs G, Cole MW, Bednarski S, Krystal JH, Bloch MH, Li CS, Pittenger C (2014) Global resting-state functional magnetic resonance imaging analysis identifies frontal cortex, striatal, and cerebellar dysconnectivity in obsessive-compulsive disorder. Biol Psychiatry 75:595-605.

Araujo DJ, Anderson AG, Berto S, Runnels W, Harper M, Ammanuel S, Rieger MA, Huang HC, Rajkovich K, Loerwald KW, Dekker JD, Tucker HO, Dougherty JD, Gibson JR, Konopka G (2015) FoxP1 orchestration of ASD-relevant signaling pathways in the striatum. Genes Dev 29:2081-2096. 
Arriaga G, Zhou EP, Jarvis ED (2012) Of mice, birds, and men: the mouse ultrasonic song system has some features similar to humans and song-learning birds. PLoS One 7:e46610.

American Psychiatric Association (2013) Diagnostic and statistical manual of mental disorders: DSM-5, Ed 5. Arlington, VA: American Psychiatric Publishing.

Autry AE, Monteggia LM (2012) Brain-derived neurotrophic factor and neuropsychiatric disorders. Pharmacol Rev 64:238-258.

Baydyuk M, Russell T, Liao GY, Zang K, An JJ, Reichardt LF, Xu B (2011) TrkB receptor controls striatal formation by regulating the number of newborn striatal neurons. Proc Natl Acad Sci USA 108:1669-1674.

Beaubien F, Raja R, Kennedy TE, Fournier AE, Cloutier JF (2016) Slitrk1 is localized to excitatory synapses and promotes their development. Sci Rep 6:27343.

Berendse HW, Galis-de Graaf Y, Groenewegen HJ (1992) Topographical organization and relationship with ventral striatal compartments of prefrontal corticostriatal projections in the rat. $\mathrm{J}$ Comp Neurol 316:314-347.

Berretta S, Parthasarathy HB, Graybiel AM (1997) Local release of GABAergic inhibition in the motor cortex induces immediate-early gene expression in indirect pathway neurons of the striatum. J Neurosci 17:4752-4763.

Björklund A, Dunnett SB (2007) Dopamine neuron systems in the brain: an update. Trends Neurosci 30:194-202.

Blundell J, Blaiss CA, Etherton MR, Espinosa F, Tabuchi K, Walz C, Bolliger MF, Südhof TC, Powell CM (2010) Neuroligin-1 deletion results in impaired spatial memory and increased repetitive behavior. J Neurosci 30:2115-2129.

Bonaventura J, Quiroz C, Cai NS, Rubinstein M, Tanda G, Ferré S (2017) Key role of the dopamine D4 receptor in the modulation of corticostriatal glutamatergic neurotransmission. Sci Adv 3:e1601631.

Bourgeron T (2015) From the genetic architecture to synaptic plasticity in autism spectrum disorder. Nat Rev Neurosci 16:551-563.

Braz BY, Galiñanes GL, Taravini IR, Belforte JE, Murer MG (2015) Altered corticostriatal connectivity and exploration/exploitation imbalance emerge as intermediate phenotypes for a neonatal dopamine dysfunction. Neuropsychopharmacology 40:2576-2587.

Buren C, Tu G, Parsons MP, Sepers MD, Raymond LA (2016) Influence of cortical synaptic input on striatal neuronal dendritic arborization and sensitivity to excitotoxicity in corticostriatal coculture. J Neurophysiol 116:380-390.

Burguière E, Monteiro P, Feng G, Graybiel AM (2013) Optogenetic stimulation of lateral orbitofronto-striatal pathway suppresses compulsive behaviors. Science 340:1243-1246.

Burguière E, Monteiro P, Mallet L, Feng G, Graybiel AM (2015) Striatal circuits, habits, and implications for obsessive-compulsive disorder. Curr Opin Neurobiol 30:59-65.

Butler AK, Uryu K, Chesselet MF (1998) A role for N-methyl-Daspartate receptors in the regulation of synaptogenesis and expression of the polysialylated form of the neural cell adhesion molecule in the developing striatum. Dev Neurosci 20:253-262.

Caubit X, Gubellini P, Andrieux J, Roubertoux PL, Metwaly M, Jacq B, Fatmi A, Had-Aissouni L, Kwan KY, Salin P, Carlier M, Liedén A, Rudd E, Shinawi M, Vincent-Delorme C, Cuisset JM, Lemaitre MP, Abderrehamane F, Duban B, Lemaitre JF, et al. (2016) TSHZ3 deletion causes an autism syndrome and defects in cortical projection neurons. Nat Genet 48:1359-1369.

Centonze D, Rossi S, Mercaldo V, Napoli I, Ciotti MT, De Chiara V, Musella A, Prosperetti C, Calabresi P, Bernardi G, Bagni C (2008) Abnormal striatal GABA transmission in the mouse model for the fragile $X$ syndrome. Biol Psychiatry 63:963-973.

Chen YC, Kuo HY, Bornschein U, Takahashi H, Chen SY, Lu KM, Yang HY, Chen GM, Lin JR, Lee YH, Chou YC, Cheng SJ, Chien CT, Enard W, Hevers W, Pääbo S, Graybiel AM, Liu FC (2016) Foxp2 controls synaptic wiring of corticostriatal circuits and vocal communication by opposing Mef2c. Nat Neurosci 19:1513-1522.

Choi S, Lovinger DM (1997) Decreased probability of neurotransmitter release underlies striatal long-term depression and postnatal development of corticostriatal synapses. Proc Natl Acad Sci USA 94:2665-2670.

Condro MC, White SA (2014) Recent advances in the genetics of vocal learning. Comp Cogn Behav Rev 9:75-98.

Costantini LC, Feinstein SC, Radeke MJ, Snyder-Keller A (1999) Compartmental expression of trkB receptor protein in the developing striatum. Neuroscience 89:505-513.

Cowan RL, Wilson CJ (1994) Spontaneous firing patterns and axonal projections of single corticostriatal neurons in the rat medial agranular cortex. J Neurophysiol 71:17-32.

Crittenden JR, Graybiel AM (2011) Basal ganglia disorders associated with imbalances in the striatal striosome and matrix compartments. Front Neuroanat 5:59-83.

Dani JW, Armstrong DM, Benowitz LI (1991) Mapping the development of the rat brain by GAP-43 immunocytochemistry. Neuroscience 40:277-287.

de Leeuw M, Kahn RS, Vink M (2015) Fronto-striatal dysfunction during reward processing in unaffected siblings of schizophrenia patients. Schizophr Bull 41:94-103.

Dehorter N, Michel FJ, Marissal T, Rotrou Y, Matrot B, Lopez C, Humphries MD, Hammond C (2011) Onset of pup locomotion coincides with loss of NR2C/D-mediated cortico-striatal EPSCs and dampening of striatal network immature activity. Front Cell Neurosci 5:24.

Delgado-Acevedo C, Estay SF, Radke AK, Sengupta A, Escobar AP, Henriquez-Belmar $F$, Reyes CA, Haro-Acuna V, Utreras $E$, Sotomayor-Zarate R, Cho A, Wendland JR, Kulkarni AB, Holmes A, Murphy DL, Chavez AE, Moya PR (2019) Behavioral and synaptic alterations relevant to obsessive-compulsive disorder in mice with increased EAAT3 expression. Neuropsychopharmacology 44: 1163-1173.

Deng Y, Lanciego J, Kerkerian-Le-Goff L, Coulon P, Salin P, Kachidian P, Lei W, Del Mar N, Reiner A (2015) Differential organization of cortical inputs to striatal projection neurons of the matrix compartment in rats. Front Syst Neurosci 9:51.

Dick AS, Bernal B, Tremblay P (2014) The language connectome: new pathways, new concepts. Neuroscientist 20:453-467.

Dickel DE, Veenstra-VanderWeele J, Cox NJ, Wu X, Fischer DJ, Van Etten-Lee M, Himle JA, Leventhal BL, Cook EH Jr, Hanna GL (2006) Association testing of the positional and functional candidate gene SLC1A1/EAAC1 in early-onset obsessive-compulsive disorder. Arch Gen Psychiatry 63:778-785.

Donoghue JP, Herkenham M (1986) Neostriatal projections from individual cortical fields conform to histochemically distinct striatal compartments in the rat. Brain Res 365:397-403.

Dubé L, Smith AD, Bolam JP (1988) Identification of synaptic terminals of thalamic or cortical origin in contact with distinct mediumsize spiny neurons in the rat neostriatum. J Comp Neurol 267:455471.

Dunlop K, Woodside B, Olmsted M, Colton P, Giacobbe P, Downar $\mathrm{J}$ (2016) Reductions in cortico-striatal hyperconnectivity accompany successful treatment of obsessive-compulsive disorder with dorsomedial prefrontal rTMS. Neuropsychopharmacology 41: 1395-1403.

Durston S, van Belle J, de Zeeuw P (2011) Differentiating frontostriatal and fronto-cerebellar circuits in attention-deficit/hyperactivity disorder. Biol Psychiatry 69:1178-1184.

Eblen F, Graybiel AM (1995) Highly restricted origin of prefrontal cortical inputs to striosomes in the macaque monkey. J Neurosci 15:5999-6013.

Ellegood J, Anagnostou E, Babineau BA, Crawley JN, Lin L, Genestine M, DiCicco-Bloom E, Lai JK, Foster JA, Peñagarikano O, Geschwind DH, Pacey LK, Hampson DR, Laliberté CL, Mills AA, Tam E, Osborne LR, Kouser M, Espinosa-Becerra F, Xuan Z, et al. (2015) Clustering autism: using neuroanatomical differences in 26 mouse models to gain insight into the heterogeneity. Mol Psychiatry 20:118-125.

Enard W, Gehre S, Hammerschmidt K, Hölter SM, Blass T, Somel M, Brückner MK, Schreiweis C, Winter C, Sohr R, Becker L, Wiebe V, Nickel B, Giger T, Müller U, Groszer M, Adler T, Aguilar A, Bolle I, 
Calzada-Wack J, et al. (2009) A humanized version of Foxp2 affects cortico-basal ganglia circuits in mice. Cell 137:961-971.

Espinosa F, Xuan Z, Liu S, Powell CM (2015) Neuroligin 1 modulates striatal glutamatergic neurotransmission in a pathway and NMDAR subunit-specific manner. Front Synaptic Neurosci 7:11.

Fettes P, Schulze L, Downar J (2017) Cortico-striatal-thalamic loop circuits of the orbitofrontal cortex: promising therapeutic targets in psychiatric illness. Front Syst Neurosci 11:25.

Figee M, Luigjes J, Smolders R, Valencia-Alfonso CE, van Wingen G, de Kwaasteniet B, Mantione M, Ooms P, de Koning P, Vulink N, Levar N, Droge L, van den Munckhof P, Schuurman PR, Nederveen A, van den Brink W, Mazaheri A, Vink M, Denys D (2013) Deep brain stimulation restores frontostriatal network activity in obsessive-compulsive disorder. Nat Neurosci 16:386-387.

Fisher SE, Scharff C (2009) FOXP2 as a molecular window into speech and language. Trends Genet 25:166-177.

Flaherty AW, Graybiel AM (1993) Two input systems for body representations in the primate striatal matrix: experimental evidence in the squirrel monkey. J Neurosci 13:1120-1137.

Flaherty AW, Graybiel AM (1994) Input-output organization of the sensorimotor striatum in the squirrel monkey. J Neurosci 14:599610.

Fremeau RT Jr, Voglmaier S, Seal RP, Edwards RH (2004) VGLUTs define subsets of excitatory neurons and suggest novel roles for glutamate. Trends Neurosci 27:98-103.

Fremeau RT Jr, Troyer MD, Pahner I, Nygaard GO, Tran CH, Reimer RJ, Bellocchio EE, Fortin D, Storm-Mathisen J, Edwards RH (2001) The expression of vesicular glutamate transporters defines two classes of excitatory synapse. Neuron 31:247-260.

Fuccillo MV (2016) Striatal circuits as a common node for autism pathophysiology. Front Neurosci 10:27.

Galiñanes GL, Taravini IR, Murer MG (2009) Dopamine-dependent periadolescent maturation of corticostriatal functional connectivity in mouse. J Neurosci 29:2496-2509.

Geng HY, Zhang J, Yang JM, Li Y, Wang N, Ye M, Chen XJ, Lian H, Li XM (2017) Erbb4 deletion from medium spiny neurons of the nucleus accumbens core induces schizophrenia-like behaviors via elevated $\mathrm{GABA}_{\mathrm{A}}$ receptor $\alpha 1$ subunit expression. J Neurosci 37: $7450-7464$

Gerfen CR (1984) The neostriatal mosaic: compartmentalization of corticostriatal input and striatonigral output systems. Nature 311: 461-464.

Gerfen CR (1989) The neostriatal mosaic: striatal patch-matrix organization is related to cortical lamination. Science 246:385-388.

Gerfen CR, Surmeier DJ (2011) Modulation of striatal projection systems by dopamine. Annu Rev Neurosci 34:441-466.

Govindan RM, Makki MI, Wilson BJ, Behen ME, Chugani HT (2010) Abnormal water diffusivity in corticostriatal projections in children with Tourette syndrome. Hum Brain Mapp 31:1665-1674.

Graham SA, Fisher SE (2015) Understanding language from a genomic perspective. Annu Rev Genet 49:131-160.

Graybiel AM (1984) Correspondence between the dopamine islands and striosomes of the mammalian striatum. Neuroscience 13: 1157-1187.

Graybiel AM (2008) Habits, rituals, and the evaluative brain. Annu Rev Neurosci 31:359-387.

Greer JM, Capecchi MR (2002) Hoxb8 is required for normal grooming behavior in mice. Neuron 33:23-34.

Groszer M, Keays DA, Deacon RM, de Bono JP, Prasad-Mulcare S, Gaub S, Baum MG, French CA, Nicod J, Coventry JA, Enard W, Fray M, Brown SD, Nolan PM, Pääbo S, Channon KM, Costa RM, Eilers J, Ehret G, Rawlins JN, et al. (2008) Impaired synaptic plasticity and motor learning in mice with a point mutation implicated in human speech deficits. Curr Biol 18:354-362.

Gunaydin LA, Kreitzer AC (2016) Cortico-basal ganglia circuit function in psychiatric disease. Annu Rev Physiol 78:327-350.

Guo Q, Wang D, He X, Feng Q, Lin R, Xu F, Fu L, Luo M (2015) Whole-brain mapping of inputs to projection neurons and cholinergic interneurons in the dorsal striatum. PLoS One 10:e0123381.
Haber SN (2016) Corticostriatal circuitry. Dialogues Clin Neurosci 18:7-21.

Harrison BJ, Soriano-Mas C, Pujol J, Ortiz H, López-Solà M, Hernández-Ribas R, Deus J, Alonso P, Yücel M, Pantelis C, Menchon JM, Cardoner N (2009) Altered corticostriatal functional connectivity in obsessive-compulsive disorder. Arch Gen Psychiatry 66:1189-1200.

Harrison BJ, Pujol J, Cardoner N, Deus J, Alonso P, López-Solà M, Contreras-Rodríguez O, Real E, Segalàs C, Blanco-Hinojo L, Menchon JM, Soriano-Mas C (2013) Brain corticostriatal systems and the major clinical symptom dimensions of obsessive-compulsive disorder. Biol Psychiatry 73:321-328.

Hintiryan H, Foster NN, Bowman I, Bay M, Song MY, Gou L, Yamashita S, Bienkowski MS, Zingg B, Zhu M, Yang XW, Shih JC, Toga AW, Dong HW (2016) The mouse cortico-striatal projectome. Nat Neurosci 19:1100-1114.

Hirschtritt ME, Lee PC, Pauls DL, Dion Y, Grados MA, Illmann C, King RA, Sandor P, McMahon WM, Lyon GJ, Cath DC, Kurlan R, Robertson MM, Osiecki L, Scharf JM, Mathews CA, Tourette Syndrome Association International Consortium for Genetics (2015) Lifetime prevalence, age of risk, and genetic relationships of comorbid psychiatric disorders in Tourette syndrome. JAMA Psychiatry 72:325-333.

Hollander E, Anagnostou E, Chaplin W, Esposito K, Haznedar MM, Licalzi E, Wasserman S, Soorya L, Buchsbaum M (2005) Striatal volume on magnetic resonance imaging and repetitive behaviors in autism. Biol Psychiatry 58:226-232.

Hong SB, Harrison BJ, Fornito A, Sohn CH, Song IC, Kim JW (2015) Functional dysconnectivity of corticostriatal circuitry and differential response to methylphenidate in youth with attention-deficit/ hyperactivity disorder. J Psychiatry Neurosci 40:46-57.

Hou JM, Zhao M, Zhang W, Song LH, Wu WJ, Wang J, Zhou DQ, Xie B, He M, Guo JW, Qu W, Li HT (2014) Resting-state functional connectivity abnormalities in patients with obsessive-compulsive disorder and their healthy first-degree relatives. J Psychiatry Neurosci 39:304-311.

Hunnicutt BJ, Jongbloets BC, Birdsong WT, Gertz KJ, Zhong H, Mao $T$ (2016) A comprehensive excitatory input map of the striatum reveals novel functional organization. Elife 5:e19103.

Inaji M, Sato K, Momose-Sato Y, Ohno K (2011) Voltage-sensitive dye imaging analysis of functional development of the neonatal rat corticostriatal projection. Neuroimage 54:1831-1839.

Jaaro-Peled H, Hayashi-Takagi A, Seshadri S, Kamiya A, Brandon NJ, Sawa A (2009) Neurodevelopmental mechanisms of schizophrenia: understanding disturbed postnatal brain maturation through neuregulin-1-ErbB4 and DISC1. Trends Neurosci 32:485495.

Jung KM, Sepers M, Henstridge CM, Lassalle O, Neuhofer D, Martin H, Ginger M, Frick A, DiPatrizio NV, Mackie K, Katona I, Piomelli D, Manzoni OJ (2012) Uncoupling of the endocannabinoid signalling complex in a mouse model of fragile $\mathrm{X}$ syndrome. Nat Commun 3:1080.

Jung WH, Yücel M, Yun JY, Yoon YB, Cho KI, Parkes L, Kim SN, Kwon JS (2017) Altered functional network architecture in orbitofronto-striato-thalamic circuit of unmedicated patients with obsessive-compulsive disorder. Hum Brain Mapp 38:109-119.

Kang C, Drayna D (2011) Genetics of speech and language disorders. Annu Rev Genomics Hum Genet 12:145-164.

Kempf L, Nicodemus KK, Kolachana B, Vakkalanka R, Verchinski BA, Egan MF, Straub RE, Mattay VA, Callicott JH, Weinberger DR, Meyer-Lindenberg A (2008) Functional polymorphisms in PRODH are associated with risk and protection for schizophrenia and fronto-striatal structure and function. PLoS Genet 4:e1000252.

Kincaid AE, Wilson CJ (1996) Corticostriatal innervation of the patch and matrix in the rat neostriatum. J Comp Neurol 374:578-592.

Konopka G, Roberts TF (2016) Insights into the neural and genetic basis of vocal communication. Cell 164:1269-1276.

Kozorovitskiy Y, Saunders A, Johnson CA, Lowell BB, Sabatini BL (2012) Recurrent network activity drives striatal synaptogenesis. Nature 485:646-650. 
Kozorovitskiy Y, Peixoto R, Wang W, Saunders A, Sabatini BL (2015) Neuromodulation of excitatory synaptogenesis in striatal development. Elife 4:e10111.

Kuo HY, Liu FC (2017) Valproic acid induces aberrant development of striatal compartments and corticostriatal pathways in a mouse model of autism spectrum disorder. FASEB J 31:4458-4471.

Lai CS, Fisher SE, Hurst JA, Vargha-Khadem F, Monaco AP (2001) A forkhead-domain gene is mutated in a severe speech and language disorder. Nature 413:519-523.

Leblond CS, Nava C, Polge A, Gauthier J, Huguet G, Lumbroso S, Giuliano F, Stordeur C, Depienne C, Mouzat K, Pinto D, Howe J, Lemière N, Durand CM, Guibert J, Ey E, Toro R, Peyre H, Mathieu A, Amsellem F, et al. (2014) Meta-analysis of SHANK mutations in autism spectrum disorders: a gradient of severity in cognitive impairments. PLoS Genet 10:e1004580.

Lee H, Sawatari A (2011) Medium spiny neurons of the neostriatal matrix exhibit specific, stereotyped changes in dendritic arborization during a critical developmental period in mice. Eur J Neurosci 34:1345-1354

Lee PS, Yerys BE, Della Rosa A, Foss-Feig J, Barnes KA, James JD, VanMeter J, Vaidya CJ, Gaillard WD, Kenworthy LE (2009) Functional connectivity of the inferior frontal cortex changes with age in children with autism spectrum disorders: a fcMRI study of response inhibition. Cereb Cortex 19:1787-1794.

Lei W, Jiao Y, Del Mar N, Reiner A (2004) Evidence for differential cortical input to direct pathway versus indirect pathway striatal projection neurons in rats. J Neurosci 24:8289-8299.

Lévesque M, Parent A (1998) Axonal arborization of corticostriatal and corticothalamic fibers arising from prelimbic cortex in the rat. Cereb Cortex 8:602-613.

Levy $F$ (1991) The dopamine theory of attention deficit hyperactivity disorder (ADHD). Aust N Z J Psychiatry 25:277-283.

Li Y, Yui D, Luikart BW, McKay RM, Li Y, Rubenstein JL, Parada LF (2012) Conditional ablation of brain-derived neurotrophic factorTrkB signaling impairs striatal neuron development. Proc Natl Acad Sci USA 109:15491-15496.

Lieberman OJ, McGuirt AF, Mosharov EV, Pigulevskiy I, Hobson BD, Choi S, Frier MD, Santini E, Borgkvist A, Sulzer D (2018) Dopamine triggers the maturation of striatal spiny projection neuron excitability during a critical period. Neuron 99:540-554.

Liégeois F, Baldeweg T, Connelly A, Gadian DG, Mishkin M, VarghaKhadem F (2003) Language fMRI abnormalities associated with FOXP2 gene mutation. Nat Neurosci 6:1230-1237.

Mailly P, Aliane V, Groenewegen HJ, Haber SN, Deniau JM (2013) The rat prefrontostriatal system analyzed in 3D: evidence for multiple interacting functional units. J Neurosci 33:5718-5727.

Martella G, Meringolo M, Trobiani L, De Jaco A, Pisani A, Bonsi P (2018) The neurobiological bases of autism spectrum disorders: the R451C-neuroligin 3 mutation hampers the expression of longterm synaptic depression in the dorsal striatum. Eur J Neurosci 47:701-708.

McGeorge AJ, Faull RL (1989) The organization of the projection from the cerebral cortex to the striatum in the rat. Neuroscience 29:503-537.

McNaught KS, Mink JW (2011) Advances in understanding and treatment of Tourette syndrome. Nat Rev Neurol 7:667-676.

Meyer-Lindenberg A, Straub RE, Lipska BK, Verchinski BA, Goldberg T, Callicott JH, Egan MF, Huffaker SS, Mattay VS, Kolachana B, Kleinman JE, Weinberger DR (2007) Genetic evidence implicating DARPP-32 in human frontostriatal structure, function, and cognition. J Clin Invest 117:672-682.

Monteiro P, Feng G (2017) SHANK proteins: roles at the synapse and in autism spectrum disorder. Nat Rev Neurosci 18:147.

Mueller A, Hong DS, Shepard S, Moore T (2017) Linking ADHD to the neural circuitry of attention. Trends Cogn Sci 21:474-488.

Mukamel Z, Konopka G, Wexler E, Osborn GE, Dong H, Bergman MY, Levitt P, Geschwind DH (2011) Regulation of MET by FOXP2, genes implicated in higher cognitive dysfunction and autism risk. J Neurosci 31:11437-11442.
Mullah SH, Inaji M, Nariai T, Momose-Sato Y, Sato K, Ohno K (2012) Optical analysis of developmental changes in synaptic potentiation in the neonatal rat corticostriatal projection. Neuroscience 201:338-348.

Nagarajan N, Jones BW, West PJ, Marc RE, Capecchi MR (2018) Corticostriatal circuit defects in Hoxb8 mutant mice. Mol Psychiatry 23:1-10.

Nakamura K, Hioki H, Fujiyama F, Kaneko T (2005) Postnatal changes of vesicular glutamate transporter (VGluT)1 and VGluT2 immunoreactivities and their colocalization in the mouse forebrain. J Comp Neurol 492:263-288.

Nakanishi M, Nomura J, Ji X, Tamada K, Arai T, Takahashi E, Bućan M, Takumi T (2017) Functional significance of rare neuroligin 1 variants found in autism. PLoS Genet 13:e1006940.

Nelson SB, Valakh V (2015) Excitatory/inhibitory balance and circuit homeostasis in autism spectrum disorders. Neuron 87:684-698.

Neves-Pereira M, Müller B, Massie D, Williams JH, O'Brien PC, Hughes A, Shen SB, Clair DS, Miedzybrodzka Z (2009) Deregulation of EIF4E: a novel mechanism for autism. J Med Genet 46: 759-765.

Newbury DF, Monaco AP (2010) Genetic advances in the study of speech and language disorders. Neuron 68:309-320.

Nisenbaum LK, Webster SM, Chang SL, McQueeney KD, LoTurco JJ (1998) Early patterning of prelimbic cortical axons to the striatal patch compartment in the neonatal mouse. Dev Neurosci 20:113124.

Olson L, Seiger A, Fuxe K (1972) Heterogeneity of striatal and limbic dopamine innervation: highly fluorescent islands in developing and adult rats. Brain Res 44:283-288.

Ozomaro U, Cai G, Kajiwara Y, Yoon S, Makarov V, Delorme R, Betancur C, Ruhrmann S, Falkai P, Grabe HJ, Maier W, Wagner M, Lennertz L, Moessner R, Murphy DL, Buxbaum JD, Züchner S, Grice DE (2013) Characterization of SLITRK1 variation in obsessive-compulsive disorder. PLoS One 8:e70376.

Paolicelli RC, Bolasco G, Pagani F, Maggi L, Scianni M, Panzanelli P, Giustetto M, Ferreira TA, Guiducci E, Dumas L (2011) Synaptic pruning by microglia is necessary for normal brain development. Science 333:1456-1458.

Park H, Poo MM (2013) Neurotrophin regulation of neural circuit development and function. Nat Rev Neurosci 14:7-23.

Park H, Popescu A, Poo MM (2014) Essential role of presynaptic NMDA receptors in activity-dependent BDNF secretion and corticostriatal LTP. Neuron 84:1009-1022.

Partridge JG, Tang KC, Lovinger DM (2000) Regional and postnatal heterogeneity of activity-dependent long-term changes in synaptic efficacy in the dorsal striatum. J Neurophysiol 84:1422-1429.

Peça J, Feliciano C, Ting JT, Wang W, Wells MF, Venkatraman TN, Lascola CD, Fu Z, Feng G (2011) Shank3 mutant mice display autistic-like behaviours and striatal dysfunction. Nature 472:437442.

Peixoto RT, Wang W, Croney DM, Kozorovitskiy Y, Sabatini BL (2016) Early hyperactivity and precocious maturation of corticostriatal circuits in Shank3B(-/-) mice. Nat Neurosci 19:716-724.

Peñagarikano O, Abrahams BS, Herman EI, Winden KD, Gdalyahu A Dong H, Sonnenblick LI, Gruver R, Almajano J, Bragin A, Golshani P, Trachtenberg JT, Peles E, Geschwind DH (2011) Absence of CNTNAP2 leads to epilepsy, neuronal migration abnormalities, and core autism-related deficits. Cell 147:235-246.

Pennartz CM, Berke JD, Graybiel AM, Ito R, Lansink CS, van der Meer M, Redish AD, Smith KS, Voorn P (2009) Corticostriatal interactions during learning, memory processing, and decision making. J Neurosci 29:12831-12838.

Phelan MC (2008) Deletion 22q13.3 syndrome. Orphanet J Rare Dis 3:14.

Plotkin JL, Wu N, Chesselet MF, Levine MS (2005) Functional and molecular development of striatal fast-spiking GABAergic interneurons and their cortical inputs. Eur J Neurosci 22:1097-1108.

Portmann T, Yang M, Mao R, Panagiotakos G, Ellegood J, Dolen G, Bader PL, Grueter BA, Goold C, Fisher E, Clifford K, Rengarajan P, Kalikhman D, Loureiro D, Saw NL, Zhengqui Z, Miller MA, Lerch 
JP, Henkelman M, Shamloo M, et al. (2014) Behavioral abnormalities and circuit defects in the basal ganglia of a mouse model of 16p11.2 deletion syndrome. Cell Rep 7:1077-1092.

Qiu A, Adler M, Crocetti D, Miller MI, Mostofsky SH (2010) Basal ganglia shapes predict social, communication, and motor dysfunctions in boys with autism spectrum disorder. J Am Acad Child Adolesc Psychiatry 49:539-551.

Qiu S, Anderson CT, Levitt P, Shepherd GM (2011) Circuit-specific intracortical hyperconnectivity in mice with deletion of the autismassociated met receptor tyrosine kinase. J Neurosci 31:58555864.

Ragsdale CW Jr, Graybiel AM (1990) A simple ordering of neocortical areas established by the compartmental organization of their striatal projections. Proc Natl Acad Sci USA 87:6196-6199.

Reimers-Kipping S, Hevers W, Pääbo S, Enard W (2011) Humanized Foxp2 specifically affects cortico-basal ganglia circuits. Neuroscience 175:75-84.

Reiner A, Jiao Y, Del Mar N, Laverghetta AV, Lei WL (2003) Differential morphology of pyramidal tract-type and intratelencephalically projecting-type corticostriatal neurons and their intrastriatal terminals in rats. J Comp Neurol 457:420-440.

Reiner A, Hart NM, Lei W, Deng Y (2010) Corticostriatal projection neurons - dichotomous types and dichotomous functions. Front Neuroanat 4:142.

Rojas DC, Peterson E, Winterrowd E, Reite ML, Rogers SJ, Tregellas JR (2006) Regional gray matter volumetric changes in autism associated with social and repetitive behavior symptoms. BMC Psychiatry 6:56-68.

Rotge JY, Guehl D, Dilharreguy B, Tignol J, Bioulac B, Allard M, Burbaud P, Aouizerate B (2009) Meta-analysis of brain volume changes in obsessive-compulsive disorder. Biol Psychiatry 65:7583.

Rothwell PE, Fuccillo MV, Maxeiner S, Hayton SJ, Gokce O, Lim BK, Fowler SC, Malenka RC, Südhof TC (2014) Autism-associated neuroligin-3 mutations commonly impair striatal circuits to boost repetitive behaviors. Cell 158:198-212.

Santini E, Huynh TN, MacAskill AF, Carter AG, Pierre P, Ruggero D, Kaphzan H, Klann E (2013) Exaggerated translation causes synaptic and behavioural aberrations associated with autism. Nature 493:411-415.

Sharpe NA, Tepper JM (1998) Postnatal development of excitatory synaptic input to the rat neostriatum: an electron microscopic study. Neuroscience 84:1163-1175.

Shepherd GM (2013) Corticostriatal connectivity and its role in disease. Nat Rev Neurosci 14:278-291.

Sheth AN, McKee ML, Bhide PG (1998) The sequence of formation and development of corticostriate connections in mice. Dev Neurosci 20:98-112.

Shmelkov SV, Hormigo A, Jing D, Proenca CC, Bath KG, Milde T, Shmelkov E, Kushner JS, Baljevic M, Dincheva I, Murphy AJ, Valenzuela DM, Gale NW, Yancopoulos GD, Ninan I, Lee FS, Rafii S (2010) Slitrk5 deficiency impairs corticostriatal circuitry and leads to obsessive-compulsive-like behaviors in mice. Nat Med 16:598-602.

Simpson EH, Kellendonk C, Kandel E (2010) A possible role for the striatum in the pathogenesis of the cognitive symptoms of schizophrenia. Neuron 65:585-596.

Smith JB, Klug JR, Ross DL, Howard CD, Hollon NG, Ko VI, Hoffman H, Callaway EM, Gerfen CR, Jin X (2016) Genetic-based dissection unveils the inputs and outputs of striatal patch and matrix compartments. Neuron 91:1069-1084.

Snyder-Keller A (2004) Pattern of corticostriatal innervation in organotypic cocultures is dependent on the age of the cortical tissue. Exp Neurol 185:262-271.

Sohur US, Padmanabhan HK, Kotchetkov IS, Menezes JR, Macklis JD (2014) Anatomic and molecular development of corticostriatal projection neurons in mice. Cereb Cortex 24:293-303.

Song M, Giza J, Proenca CC, Jing D, Elliott M, Dincheva I, Shmelkov SV, Kim J, Schreiner R, Huang SH, Castrén E, Prekeris R, Hempstead BL, Chao MV, Dictenberg JB, Rafii S, Chen ZY, Rodriguez-
Boulan E, Lee FS (2015) Slitrk5 mediates BDNF-dependent TrkB receptor trafficking and signaling. Dev Cell 33:690-702.

Stillman AA, Krsnik Z, Sun J, Rasin MR, State MW, Sestan N, Louvi A (2009) Developmentally regulated and evolutionarily conserved expression of SLITRK1 in brain circuits implicated in Tourette syndrome. J Comp Neurol 513:21-37.

Sudhof TC (2008) Neuroligins and neurexins link synaptic function to cognitive disease. Nature 455:903-911.

Takahashi H, Katayama K, Sohya K, Miyamoto H, Prasad T, Matsumoto Y, Ota M, Yasuda H, Tsumoto T, Aruga J, Craig AM (2012) Selective control of inhibitory synapse development by Slitrk3PTP $\delta$ trans-synaptic interaction. Nat Neurosci 15:389-398, S1-2.

Tan HY, Nicodemus KK, Chen Q, Li Z, Brooke JK, Honea R, Kolachana BS, Straub RE, Meyer-Lindenberg A, Sei Y (2008) Genetic variation in AKT1 is linked to dopamine-associated prefrontal cortical structure and function in humans. J Clin Invest 118:22002208.

Tasic B, Menon V, Nguyen TN, Kim TK, Jarsky T, Yao Z, Levi B, Gray LT, Sorensen SA, Dolbeare T, Bertagnolli D, Goldy J, Shapovalova N, Parry S, Lee C, Smith K, Bernard A, Madisen L, Sunkin SM, Hawrylycz M, et al. (2016) Adult mouse cortical cell taxonomy revealed by single cell transcriptomics. Nat Neurosci 19:335-346.

Tepper JM, Sharpe NA, Koós TZ, Trent F (1998) Postnatal development of the rat neostriatum: electrophysiological, light- and electron-microscopic studies. Dev Neurosci 20:125-145.

Thiselton DL, Vladimirov VI, Kuo P-H, McClay J, Wormley B, Fanous A, O'Neill FA, Walsh D, Van den Oord EJ, Kendler KS (2008) AKT1 is associated with schizophrenia across multiple symptom dimensions in the Irish study of high density schizophrenia families. Biol Psychiatry 63:449-457.

Tischfield DJ, Saraswat DK, Furash A, Fowler SC, Fuccillo MV, Anderson SA (2017) Loss of the neurodevelopmental gene Zswim6 alters striatal morphology and motor regulation. Neurobiol Dis 103:174-183

Toro R, Konyukh M, Delorme R, Leblond C, Chaste P, Fauchereau F, Coleman M, Leboyer M, Gillberg C, Bourgeron T (2010) Key role for gene dosage and synaptic homeostasis in autism spectrum disorders. Trends Genet 26:363-372.

Uryu K, Butler AK, Chesselet MF (1999) Synaptogenesis and ultrastructural localization of the polysialylated neural cell adhesion molecule in the developing striatum. J Comp Neurol 405:216-232. van der Kooy D (1984) Developmental relationships between opiate receptors and dopamine in the formation of caudate-putamen patches. Dev Brain Res 14:300-303.

Veenstra-VanderWeele J, Kim SJ, Gonen D, Hanna GL, Leventhal BL, Cook EH Jr (2001) Genomic organization of the SLC1A1/ EAAC1 gene and mutation screening in early-onset obsessivecompulsive disorder. Mol Psychiatry 6:160-167.

Vernes SC, Newbury DF, Abrahams BS, Winchester L, Nicod J, Groszer M, Alarcón M, Oliver PL, Davies KE, Geschwind DH, Monaco AP, Fisher SE (2008) A functional genetic link between distinct developmental language disorders. N Engl J Med 359: 2337-2345.

Wagshal D, Knowlton BJ, Suthana NA, Cohen JR, Poldrack RA, Bookheimer SY, Bilder RM, Asarnow RF (2014) Evidence for corticostriatal dysfunction during cognitive skill learning in adolescent siblings of patients with childhood-onset schizophrenia. Schizophr Bull 40:1030-1039.

Wall NR, De La Parra M, Callaway EM, Kreitzer AC (2013) Differential innervation of direct- and indirect-pathway striatal projection neurons. Neuron 79:347-360.

Wan Y, Ade KK, Caffall Z, Ilcim Ozlu M, Eroglu C, Feng G, Calakos $N$ (2014) Circuit-selective striatal synaptic dysfunction in the Sapap3 knockout mouse model of obsessive-compulsive disorder. Biol Psychiatry 75:623-630.

Watkins KE, Gadian DG, Vargha-Khadem F (1999) Functional and structural brain abnormalities associated with a genetic disorder of speech and language. Am J Hum Genet 65:1215-1221. 
Welch JM, Lu J, Rodriguiz RM, Trotta NC, Peca J, Ding JD, Feliciano C, Chen M, Adams JP, Luo J, Dudek SM, Weinberg RJ, Calakos N, Wetsel WC, Feng G (2007) Cortico-striatal synaptic defects and OCD-like behaviours in Sapap3-mutant mice. Nature 448:894900.

Wendland JR, Moya PR, Timpano KR, Anavitarte AP, Kruse MR, Wheaton MG, Ren-Patterson RF, Murphy DL (2009) A haplotype containing quantitative trait loci for SLC1A1 gene expression and its association with obsessive-compulsive disorder. Arch Gen Psychiatry 66:408-416.

Wingate M, Kirby RS, Pettygrove S, Cunniff C, Schulz E, Ghosh T, Robinson C, Lee LC, Landa R, Constantino J, Fitzgerald R, Zahorodny W, Daniels J, Nicholas J, Charles J, McMahon W, Bilder D, Durkin M, Baio J, Christensen D, et al. (2014) Prevalence of autism spectrum disorder among children aged 8 years - autism and developmental disabilities monitoring network, 11 sites, United States, 2010. MMWR Surveill Summ 63:1-21.

Worbe $Y$, Marrakchi-Kacem L, Lecomte S, Valabregue R, Poupon F, Guevara P, Tucholka A, Mangin JF, Vidailhet M, Lehericy S, Hartmann A, Poupon C (2015) Altered structural connectivity of cortico-striato-pallido-thalamic networks in Gilles de la Tourette syndrome. Brain 138:472-482.
Wu Y, Dissing-Olesen L, MacVicar BA, Stevens B (2015) Microglia: dynamic mediators of synapse development and plasticity. Trends Immunol 36:605-613.

Yim YS, Kwon Y, Nam J, Yoon HI, Lee K, Kim DG, Kim E, Kim CH, Ko J (2013) Slitrks control excitatory and inhibitory synapse formation with LAR receptor protein tyrosine phosphatases. Proc Natl Acad Sci USA 110:4057-4062.

Zerbi V, lelacqua GD, Markicevic M, Haberl MG, Ellisman $M H$, A-Bhaskaran A, Frick A, Rudin M, Wenderoth N (2018) Dysfunctional autism risk genes cause circuit-specific connectivity deficits with distinct developmental trajectories. Cereb Cortex 28:2495-2506.

Zike ID, Chohan MO, Kopelman JM, Krasnow EN, Flicker D, Nautiyal KM, Bubser M, Kellendonk C, Jones CK, Stanwood G, Tanaka KF, Moore H, Ahmari SE, Veenstra-VanderWeele J (2017) OCD candidate gene SLC1A1/EAAT3 impacts basal ganglia-mediated activity and stereotypic behavior. Proc Natl Acad Sci USA 114:57195724.

Züchner S, Wendland JR, Ashley-Koch AE, Collins AL, Tran-Viet KN, Quinn K, Timpano KC, Cuccaro ML, Pericak-Vance MA, Steffens DC, Krishnan KR, Feng G, Murphy DL (2009) Multiple rare SAPAP3 missense variants in trichotillomania and OCD. Mol Psychiatry $14: 6-9$. 